\title{
Antibacterial Activity of Cetyltrimethylammonium Bromide Modified Silver-Bentonite
}

\author{
Nik Ahmad Nizam Nik Malek, Wan Nur Azalisa, Clara Chong Yieh Lin \\ Faculty of Biosciences and Medical Engineering, Universiti Teknologi Malaysia, 81310 UTM, Skudai, Johor, Malaysia
}

\begin{abstract}
Organo-Ag-bentonite was prepared by the attachment of cationic surfactant cetyltrimethylammonium bromide on silver(A)g-exchanged bentonite. The prepared samples were characterized by X-ray diffraction (XRD), Fourier transform infrared (FTIR) spectroscopy and energy dispersive X-ray (EDX) analysis and antibacterial assay was performed against Escherichia coli in different percentage of saline solutions through minimum inhibition concentration (MIC) method. Organo-Ag-bentonite showed higher antibacterial activity than organo-bentonite and Ag-bentonite especially in saline solution suggesting that the precipitation of $\mathrm{AgCl}$ in the presence of Ag-bentonite in saline solution could be avoided by the attachment of cationic surfactant on Ag-bentonite surfaces, hence increased their antibacterial activity.
\end{abstract}

\section{Introduction}

For centuries, silver (Ag) has been well known for its antibacterial [1] and medicinal properties [2]. Because of this, Ag based products have been widely developed nowadays as antibacterial agent. The examples included Ag nanoparticles [3], Ag nanocomposite [4] and Ag sulfadiazine [5]. On the other hand, there are also various innovative Ag based products which have been produced and studied recently such as sutures modified by Agloaded montmorillonite [6], Ag nanoparticle-ionic silsesquioxane [7], nano-Ag fluoride in treating dental decay in children [8] and incorporation of silver nanoparticles into acrylic bone cement [9].

Exploring an improved Ag based products that can control the release of $\mathrm{Ag}$ ions into the environment is crucial since there were some reports on the toxicity of silver nanoparticles on a common grass, Lollium multiflorum [10], freshwater alga Ochromonas danica [11] and aquatic custaceans (Daphnia magna and Thamnocephalus platyurus) [12]. The use of inorganic carrier to support antibacterial compounds could increase their antibacterial efficiency and could control the release of $\mathrm{Ag}$ ions. In previous studies, some of the ideal carrier system for antibacterial agents were montmorrilonite (a type of clay) [13-15], kaolinite [16], zeolite [17-19] and bentonite [20-21].

Besides that, the antimicrobial activity of $\mathrm{Ag}$ based products has shown to decrease in solution containing electrolyte [17]. The present of chloride ions $\left(\mathrm{Cl}^{-}\right)$in saline solution tend to reduce the number of $\mathrm{Ag}$ ions due to the formation of $\mathrm{AgCl}$ precipitate. As $\mathrm{Ag}$ ions are the main agent in killing the bacteria cells, reduction in the number of Ag ions will eventually lower its antibacterial activity. In order to solve this issue, combination of $\mathrm{Ag}$ ions with cationic surfactant QAC might be useful [17]. Among all the surfactant, quaternary ammonium compounds (QAC) is the choice as it is known to be the most useful antiseptics and disinfectants and it is claimed to have a great affinity towards chloride or bromide ions. Therefore, combination of cationic surfactant and $\mathrm{Ag}$ could be developed on the support system such as bentonite. Cationic surfactant and Ag supported on the bentonite could firstly be prepared by loading bentonite with $\mathrm{Ag}$ ions [13] from $\mathrm{AgNO}_{3}$ solution through ions exchange technique [15] so that the Ag ions are located inside the bentonite framework structure followed by the attachment of the cationic surfactant on the prepared Agbentonite $[17,20]$.

The aim of this study was to prepare and characterize organo-Ag-bentonite; cationic surfactant QAC loaded on Ag exchanged bentonite. The antibacterial activity of the organo-Ag-bentonite was studied against Escherichia coli in different percentage of saline solutions through minimum inhibition concentration (MIC) method in order to prove their antibacterial efficiency in different concentration of electrolyte (chloride ions).

\section{Materials and Methods}

\subsection{Materials}

Bentonite was purchased from Sigma-Aldrich. Source of $\mathrm{Ag}$ ions and surfactant were taken from $\mathrm{AgNO}_{3}$ (Merck) and cetyltrimethylammonium bromide (CTAB) (Merck), respectively. For the antibacterial assay, saline solution was prepared by dissolving an appropriate amount of 
$\mathrm{NaCl}$ (Merck) in distilled water. Luria-Bertani (LB) broth and nutrient agar (NA) as growth medium for bacteria were purchased from Sigma-Aldrich.

\subsection{Preparation of Samples}

Silver modified bentonite (AgBent-S1) was firstly prepared by mixing bentonite (Bent-S) (10 g) with 1000 ppm $\mathrm{AgNO}_{3}$ solution $(1000 \mathrm{~mL})$. The suspension was stirred using a magnetic stirrer for 16-17 hours and the solid fraction was collected by filtration system using Whatman filter paper. The solid residue was dried in an oven at $90^{\circ} \mathrm{C}$ overnight. The dried AgBent-S1 was further treated with $\mathrm{AgNO}_{3}$ solution again to produce AgBent-S2 for the higher amount of $\mathrm{Ag}$ ions in the bentonite than AgBent-S1. CTAB-bentonite (CTAB-Bent-S) and CTAB modified Ag-bentonite (CTAB-AgBent-S-1 and CTABAgBent-S-2) were prepared by mixing $2.0 \mathrm{mM}$ CTAB solution $(200 \mathrm{~mL})$ with bentonite $(5.0 \mathrm{~g})$, AgBent-S1 (5.0 g) and AgBent-S2 (5.0 g), respectively. The suspensions were stirred, filtered and dried similar to that of preparation of AgBent-S1.

\subsection{Characterization}

Bent-S and AgBent-S1 were characterized by X-ray diffraction (XRD) and energy dispersive X-ray (EDX) analyzer. XRD patterns were recorded using a Bruker D8 Advance diffractometer with these parameters: $\mathrm{CuK} \alpha_{1}$ radiation with $\lambda=1.5418 \AA, 40 \mathrm{kV}, 20 \mathrm{~mA}, 2 \theta=5^{\circ}$ to $50^{\circ}$, scanning speed of $0.05^{\circ}$ per second. The major elements especially the presence of Ag was detected by EDX (CARL ZEISS 35 VP Supra) with JED-2300 analysis station as a detector. All samples were characterized by Fourier-transform infrared (FTIR) spectroscopy (Nicolet ${ }^{\mathrm{TM}}$ iS ${ }^{\mathrm{TM}} 5$ FT-IR Spectrometer) equipped with attenuated total reflectance (ATR) technique.

\subsection{Antibacterial Assay}

In the antibacterial assay, E. coli was used as a model bacteria through the determination of minimum inhibitory concentration (MIC) in distilled water and different concentrations of saline solution. E. coli was taken from the collection of bacteria culture in Microbiology Laboratory, Faculty of Bioscience and Medical Engineering, UTM and the bacteria was originally supplied by Institute Medical Research (IMR), Kuala Lumpur, Malaysia. Method for determination of MIC values for each sample was carried out based on procedure described elsewhere [17] but with different solutions. In the last stage, the $E$. coli cells were dispersed in distilled water and three different concentrations of saline solution: $0.1,1.0$ and $5.0 \%$. The $E$. coli suspension was added with the samples at different concentration: $0.1 \mathrm{~g} / \mathrm{L}, 0.5 \mathrm{~g} / \mathrm{L}, 1.0 \mathrm{~g} / \mathrm{L}, 2.0 \mathrm{~g} / \mathrm{L}$, $5.0 \mathrm{~g} / \mathrm{L}, 8.0 \mathrm{~g} / \mathrm{L}$ and $10.0 \mathrm{~g} / \mathrm{L}$. The suspension was incubated in incubator shaker with agitation rate of 100 rpm for 30 minutes. After that, $10 \mu \mathrm{L}$ of solution from the suspension was dropped on the NA plate of nutrient agar using the dropped plate technique [22]. The plate was then incubated in incubator at $37^{\circ} \mathrm{C}$ for 8 hours and finally, the plate was observed for the growth of bacteria. MIC value was determined by the lowest concentration that can kill the whole colony of bacteria.

\section{Results and Discussion}

\subsection{Characterization of Studied Materials}

Fig. 1 shows XRD patterns of raw bentonite (Bent-S) and Ag-bentonite (AgBent-S1). The XRD patterns shows that the major phase is montmorillonite $(\mathrm{M})$ and other minor phases present in the sample are illite (I), quartz $(\mathrm{Q})$ and kaolinite $(K)$ [23]. There were no changes in the XRD patterns of both samples indicating that the structure of bentonite was stable after loaded with Ag cations [24]. Characterizations of both samples were further performed by elemental analysis qualitatively using EDX (Fig. 2). The EDX spectrum of Ag-Bent-S indicates the presence of $\mathrm{Ag}$ but absence in raw bentonite (Bent-S).

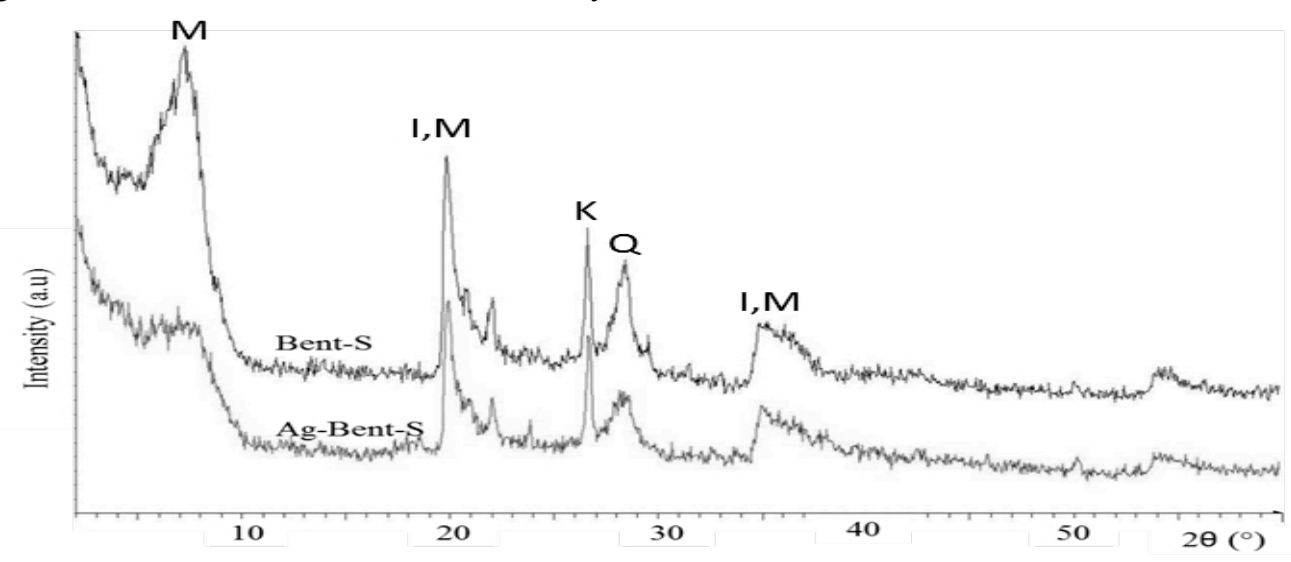

Figure 1. XRD of Bent-S and Ag-Bent-S (M: Montmorillonite, I: Illite, K: Kaolinite, Q: Quartz). 


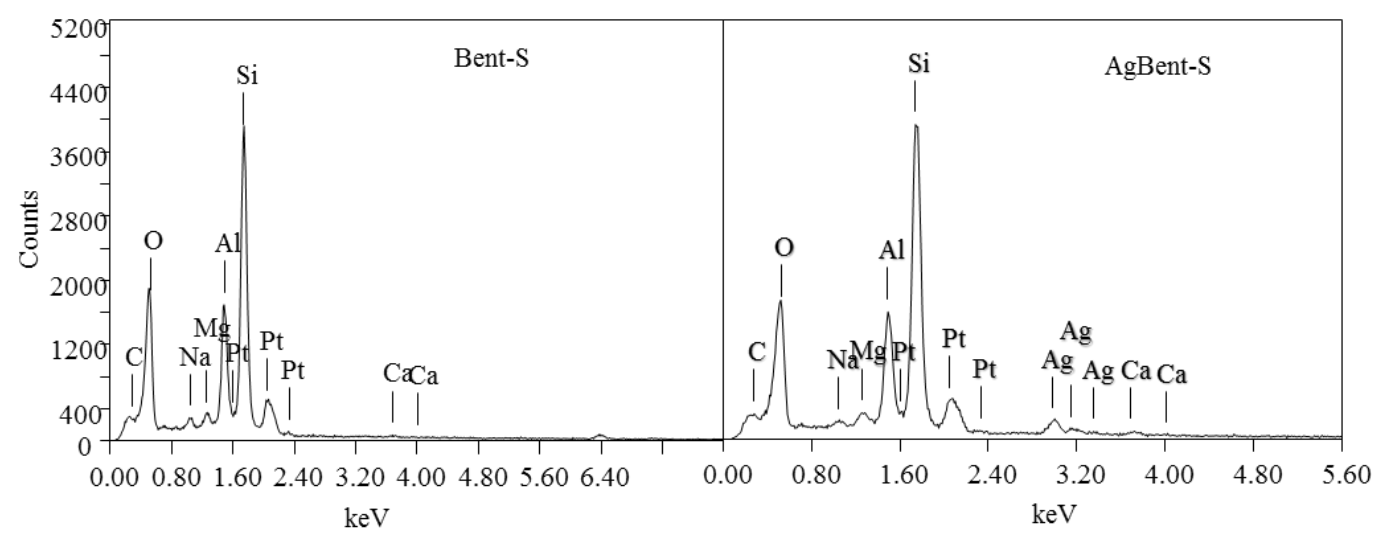

Figure 2. EDX spectra of Bent-S and Ag-Bent-S.

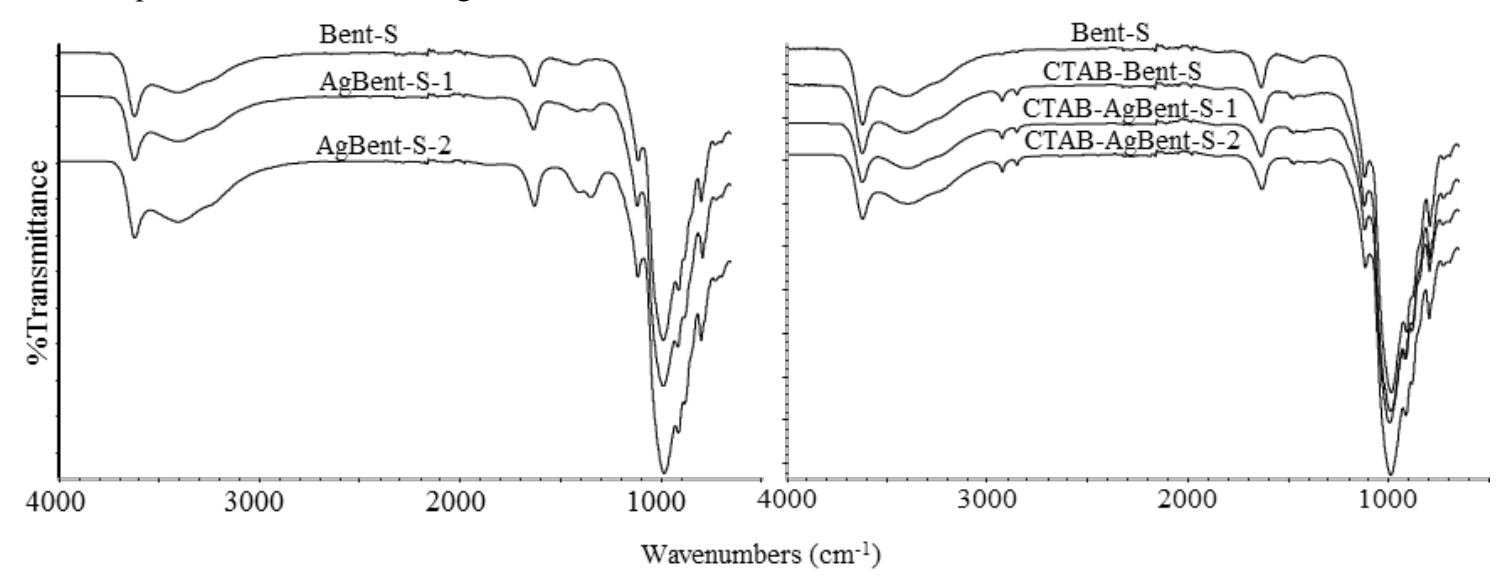

Figure 3. FTIR spectra of the samples.

FTIR spectra of Ag-bentonite (AgBent-S), CTAB modified bentonite (CTAB-Bent-S) and CTAB modified Ag-bentonite (CTAB-AgBent-S) are given in Fig. 3. Each FTIR spectra was compared with that of raw bentonite (Bent-S). Two important findings can be obtained from the FTIR spectra of the samples: (1) the structural stability after modification, and (2) the presence of CTAB molecules on the bentonite. All FTIR spectra showed the presence of similar peaks in the range of $1100-600 \mathrm{~cm}^{-1}$. In this range, there are peaks related to stretching vibration of Si-O groups, Al-O-Si and Si-O-Si bending vibrations and $\mathrm{Al}-\mathrm{O}$ and $\mathrm{Si}-\mathrm{O}$ out of plane vibrations of bentonite framework structure [24]. Thus, these FTIR spectra show the structural stability of bentonite after modification with Ag and CTAB [17]. On the other hand, the presence of CTAB in CTAB modified bentonite and Ag-bentonite can be proven by the emergence of two additional peaks at 2850 and $2920 \mathrm{~cm}^{-1}$. These two peaks are assigned to the asymmetric ( 2850 $\left.\mathrm{cm}^{-1}\right)$ and symmetric $\left(2920 \mathrm{~cm}^{-1}\right)$ stretching vibrations of $\mathrm{C}-\mathrm{H}$ in the alkyl chain of CTAB [25]. Fig. 3 clearly indicates that the FTIR spectra of CTAB-Bent-S and CTAB-Ag-Bent-S possess these two additional peaks confirming the attachment of CTAB molecules on bentonite and Ag-bentonite surfaces.

Findings from XRD, EDX and FTIR validated the modification of bentonite with Ag (AgBent-S) and CTAB (CTAB-Bent-S) and also, the attachment of CTAB on Ag-bentonite creating organo-Ag-bentonite (CTAB-
AgBent-S). Additionally, results from XRD and FTIR show that the bentonite structure remains stable after modification since the modification process of $\mathrm{Ag}$ and $\mathrm{CTAB}$ on bentonite occurred via ion exchanged process without affecting the structure of bentonite [17].

\subsection{Antibacterial Activity}

Table 1. MIC values of studied samples against E. coli.

\begin{tabular}{|c|c|c|c|c|}
\hline \multirow{2}{*}{ Sample } & \multicolumn{4}{|c|}{ MIC [g/L] } \\
\cline { 2 - 5 } & \multirow{2}{*}{ Distilled water } & \multicolumn{2}{|c|}{ Saline solution [\%] } \\
\cline { 2 - 5 } & & $\mathbf{0 . 1}$ & $\mathbf{1 . 0}$ & $\mathbf{5 . 0}$ \\
\hline Bent-S & $>10$ & $>10$ & $>10$ & $>10$ \\
\hline AgBent-S1 & 0.5 & 0.8 & 3 & $>10$ \\
\hline AgBent-S2 & 0.1 & 0.5 & 2 & $>10$ \\
\hline C-Bent-S & $>10$ & $>10$ & $>10$ & $>10$ \\
\hline CTAB-AgBent-S-1 & 0.5 & 2 & 2 & 5 \\
\hline CTAB-AgBent-S-2 & 0.1 & 0.5 & 1.0 & 1.0 \\
\hline
\end{tabular}

The antibacterial activity of each sample was performed against E. coli (Gram negative bacteria) through the determination of minimum inhibition concentration (MIC) values in distilled water and saline solution with different concentrations $(0.1,1.0$ and $5.0 \%)$. The lower MIC value indicates better antibacterial activity since only small amount of sample is needed to kill the whole bacteria or to inhibit the bacterial growth. Table 1 gives MIC values for each sample. 
Raw bentonite (Bent-S) and CTAB modified bentonite (C-Bent-S) have no antibacterial activity against $E$. coli in distilled water and saline solutions (MIC values $>10 \mathrm{~g} / \mathrm{L}$ ). Raw bentonite did not show any antibacterial activity because there were no antibacterial elements e.g. antibacterial metal $(\mathrm{Cu}, \mathrm{Zn}$ and $\mathrm{Ag})$ present in the sample according to the elemental analysis of raw bentonite by EDX (Fig. 2). CTAB on its own (free CTAB) has antibacterial activity [13] however, the antibacterial activity of CTAB was reduced after loaded on bentonite because of the attachment of CTAB molecules on bentonite prevents the movement of CTAB molecules in the solution. This result is in agreement with the work done by Malachova et al. [13] where CTAB modified montmorillonite showed lower antibacterial effects by 18 orders of magnitude as compared to CTAB itself.

Generally, the antibacterial activity of the Agbentonite depends on the amount of $\mathrm{Ag}$ in the sample where the antibacterial activity followed these trends: AgBent-S2>AgBent-S1 and CTAB-AgBent-S-2>CTABAgbent-S-1. This result showed that the antibacterial activity of bentonite was enhanced by the Ag ions inside the bentonite. The antibacterial assay was carried out in solution where the samples in powder form were added in bacteria solution either in distilled water or saline solution. Thus, the Ag ions could release into the solution from bentonite framework and eventually kill the bacteria cells $[13,15]$. Additionally, the antibacterial activity of the Ag-bentonite was also affected by different concentrations of saline solution $(0.1 \%>1.0 \%>5.0 \%)$. At $5.0 \%$ of saline solution, Ag-bentonite showed no antibacterial activity. This is mainly due to the reaction between $\mathrm{Ag}$ ions that released from bentonite with the chloride ions in the saline solution forming precipitate $\mathrm{AgCl}[13,26]$. Precipitation of the $\mathrm{AgCl}$ in the bacteria solution reduced the antibacterial activity since the free Ag ions are no longer exist in the bacteria solution to kill the bacteria.

From MIC values of the samples, it is observed that the modification of Ag-bentonite by CTAB (CTABAgBent-S) could increase the antibacterial activity of Agbentonite especially in the highest concentration of saline solution $(5.0 \%)$. The antibacterial activity of CTAB modified Ag-bentonite did not affected by the saline solution and this is certainly due to the presence of CTAB on the bentonite surfaces. This can be understood by the mechanism of surfactant attachment on clay framework. It is well-known for a long time that surfactant modified clay or organoclay has the ability to adsorb and retain anionic compound [27-29]. Due to the molecular structure of cationic surfactant like CTAB that consists of two essential parts: (1) head positive group of quaternary ammonium and (2) hydrophobic tail of hydrocarbon chain $(\mathrm{C} 16)$ and the capability of this surfactant to form micelles in the solution, the attachment of cationic surfactant on clay creates organic rich layer on the clay surfaces [16]. The configuration of cationic surfactant molecules on clay surfaces is affected by the concentration or the amount of cationic surfactant in the initial solution (before attachment on clay surfaces). The excess amount of cationic surfactant molecules creating double layer configuration of the molecules on the clay surfaces generated by two main bonding in two surfactant layers: (1) electrostatic bonding between positive head group of cationic surfactant with negative charge framework of clay at the first layer and (2) hydrophobic bonding among cationic surfactant molecules through tail-tail interaction of hydrocarbon tail of surfactant at the second layer [16]. Because of the attachment of cationic surfactant on clay surface, the surfactant modified clay is capable of adsorbing and retaining anionic compounds. In relation to this study, possible reason for the enhanced antibacterial activity for CTAB modified Ag-bentonite is due to the uptake of chloride ions by surfactant molecules on bentonite layer and thus prevents the formation of silver chloride in the solution. This increased the Ag ions in the high concentration of saline solution and eventually kill the bacteria by the action of Ag ions.

\section{Conclusion}

Organo-Ag-bentonite was prepared without affecting the original structure of bentonite and showed higher antibacterial activity than both CTAB-bentonite and Agbentonite especially in saline solution. Therefore, organoAg-bentonite can be an alternative antibacterial agent that can replace other Ag based products due to its stability and high antibacterial activity for wide spectrum of bacteria. This modification is also useful in preventing the reduction of antibacterial activity of $\mathrm{Ag}$ based products in solution that contain chloride ions.

\section{Acknowledgements}

Authors would like to thanks Ministry of Education (MoE), Malaysia and Universiti Teknologi Malaysia (UTM) for financial support under Fundamental Research Grant Scheme (FRGS) (Vot No: 4F514) and Faculty of Biosciences and Medical Engineering, UTM.

\section{References}

1. P. Praus, M. Turicová and M. Valášková: J. Brazil. Chem. Soc. Vol. 19 (2008), p. 549.

2. B.S. Atiyeh, M. Costagliola, S.N. Hayek and S.A. Dibo: Burns. Vol. 33 (2007), p.139.

3. S. Rajakannu, S. Shankar, S. Perumal, S. Subramanian and G.P. Dhakshinamoorthy: Int. J. Curr. Microbiol. Appl. Sci. Vol. 4 (2015), p. 944.

4. G. Yang, C. Wang, F. Hong, X. Yang and Z. Cao: Carbohyd. Polym. Vol. 115 (2015), p. 636.

5. C. Aguzzi, G. Sandri, C. Bonferoni, P. Cerezo, S. Rossi, F. Ferrari, C. Caramella and C. Viseras: Colloid Surface B. Vol. 113 (2014), p. 152.

6. G.F. Cao, Y. Sun, J.G. Chen, L.P. Song, J.Q. Jiang, Z.T. Liu and Z.W. Liu: Appl. Clay Sci. Vol. 93 (2014), p. 102.

7. A.C. Schneid, E.W. Roesch, F. Sperb, U. Matte, N.P. da Silveira, T.M.H. Costa, E.V. Benvenutti and E.W. de Menezes: J. Mater. Chem. B. Vol. 2(8) (2014), p. 1079 . 
8. A.G.R. Targino, M.A.P. Flores, V.E. dos Santos Junior, F.D.G.B. Bezerra, H. de Luna Freire, A. Galembeck and A. Rosenblatt: J. Mater. Sci.-Mater. Med. Vol. 25(8) (2014), p. 2041.

9. J. Slane, J. Vivanco, W. Rose, H.L. Ploeg and M. Squire: Mater. Sci. Eng. C. Vol. 48 (2015) p. 188.

10. L. Yin, Y. Cheng, B. Espinasse, B.P. Colman, M. Auffan, M. Wiesner, J. Rose, J. Liu and E.S. Bernhardt: Environ. Sci. Technol. Vol. 45(6) (2011), p. 2360.

11. A. J. Miao, Z. Luo, C. S. Chen, W.C. Chin, P.H. Santschi and A. Quigg: PLoS One, Vol. 5(12) (2010), p. e15196.

12. I. Blinova, J. Niskanen, P. Kajankari, L. Kanarbik, A. Käkinen, H. Tenhu, O.P. Penttinen and A. Kahru: Environ. Sci. Pollut. Res. Vol. 20(5) (2013), p. 3456.

13. K. Malachova, P. Praus, Z. Pavlíčková and M. Turicová: Appl. Clay Sci. Vol. 43 (2009), p. 364

14. K. Malachová, P. Praus, Z. Rybková and O. Kozák: Appl. Clay Sci. Vol. 53(4) (2011), p. 642.

15. S.M. Magana, P. Quintana, D.H. Aguilar, J.A. Toledo, C. Ángeles-Chávez, M.A. Cortés, L. León, Y. Freile-Pelegrín, T. López and R.M.T. Sánchez: J. Mol. Catal. A.-Chem. Vol. 281(1) (2008), p. 192.

16. N.A.N.N. Malek, N.I. Ramli: Appl. Clay Sci. Vol. 119-110 (2015), p. 8.

17. N.A.N.N. Malek, C.D. Williams, S. Dhanabal, H.S. Bhall and N. Ibrahim: Appl. Mech. Mater. Vol. 606 (2014), p.29.
18. Y. Matsumura, K. Yoshikata, S.I. Kunisaki and T. Tsuchido: Appl. Environ. Microbiol. Vol. 69(7) (2003), p. 4278.

19. B. Kwakye-Awuah, C. Williams. M.A. Kenward and I. Radecka: J. Appl. Microbiol. Vol. 104(5) (2008), p. 1516.

20. N.A.N.N. Malek, S.A. Ishak and M.R.A. Kadir: Adv. Mater. Res. Vol. 626 (2013), P. 178.

21. M.F. Santos, C.M. Oliveira, C.T. Tachinski, M.P. Fernandes, C.T. Pich, E. Angioletto, H.G. Riella and M.A. Fiori: Int. J. Miner. Process. Vol. 100(1) (2011), p. 51 .

22. B. Herigstad, M. Hamilton and J. Heersink: J. Microbiol. Method, Vol. 44(2) (2001), p.121.

23. M. Sarkar, K. Dana, S. Ghatak and A. Banerjee: Bull. Mater. Sci. Vol. 31(1) (2008), p. 23.

24. E. Eren and B. Afsin: J. Hazard. Mater. Vol. 151(2) (2008), p. 682.

25. Z. Li and L. Gallus: Appl. Clay. Sci. Vol. 35(3) (2007), p. 250.

26. O. Choi, K.K. Deng, N.J. Kim, L. Ross Jr, R.Y. Surampalli and Z. Hu: Water Res. Vol. 42(12) (2008), p. 3066.

27. Z. Li and R.S. Bowman: Environ. Eng. Sci. Vol. 15(3) (1998), p. 237.

28. S.A. Boyd, M.M. Mortland and C.T. Chiou: Soil Sci. Soc. Am. J. Vol. 52(3) (1988), p. 652.

29. Z. Li; J. Environ. Qual. Vol. 28(5) (1999), p. 1457. 